\title{
Interaction of Polymorphonuclear Neutrophils
}

\section{with Escherichia Coli}

\author{
EFFECT OF ENTEROTOXIN ON PHAGOCYTOSIS, KILLING, \\ CHEMOTAXIS, AND CYCLIC AMP
}

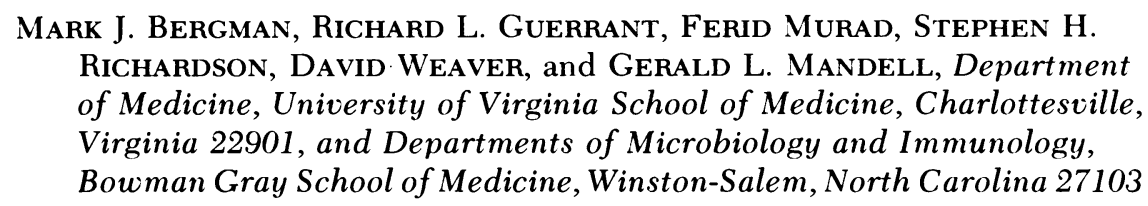

A B S T R A C T Enterotoxigenic Escherichia coli are associated with noninflammatory diarrhea and stimulate adenylate cyclase activity of mammalian cells, thereby increasing intracellular cyclic adenosine $3^{\prime}, 5^{\prime}$-monophosphate (cyclic AMP). Increased concentrations of cyclic AMP in polymorphonuclear neutrophils (PMN) inhibit phagocytosis, candidacidal activity, granule discharge, and chemotactic responsiveness. We examined the effect of enterotoxin on the interaction of human $\mathrm{PMN}$ with E. coli. Enterotoxigenic and nonenterotoxigenic strains, including serotypes of $E$. coli identical except for the presence or absence of the plasmid coding for enterotoxin production, were utilized. Enterotoxigenic and nonenterotoxigenic $E$. coli, tumbled with PMN, were phagocytized and killed (>97\%) equally well, and these strains stimulated PMN hexose monophosphate shunt activity equivalently.

However, a chemotaxis assay under agarose demonstrated that filtrates of 10 enterotoxigenic strains were less chemotactic for PMN by $15 \pm 2 \%$ total migration or $46 \pm 1 \%$ directed migration, when compared with 6 nonenterotoxigenic strains $(P<0.001)$. Inactivation of the enterotoxin by heat $\left(65^{\circ} \mathrm{C}\right.$ for $\left.30 \mathrm{~min}\right)$ or antibodies formed to $E$. coli enterotoxin eliminated the inhibitory effect of the enterotoxic filtrates for PMN chemotaxis. Addition of purified $E$. coli enterotoxin directly to the PMN decreased chemotaxis to E. coli filtrates by 32 $\pm 2 \%(P<0.001)$. These data suggest that the effect was

This work was presented in part at the National Meeting of the American Federation for Clinical Research, May 1977, Clin. Res. 25: 372A. (Abstr.)

Dr. Guerrant is George Morris Piersol Teaching and Research Scholar of the American College of Physicians.

Received for publication 14 December 1976 and in revised form 15 September 1977. due to the heat-labile enterotoxin. The phosphodiesterase inhibitor, 1-methyl-3-isobutylxanthine $(0.1 \mathrm{mM})$, which potentiates effects due to an increase in intracellular cyclic AMP, further decreased total PMN migration (random plus directed) toward enterotoxic filtrates to $46 \%$ of that to nonenterotoxic filtrates ( $P$ $<0.001)$. Addition of cholera toxin $(1 \mu \mathrm{g} / \mathrm{ml})$, which is similar to $E$. coli enterotoxin, to the PMN inhibited total migration toward nonenterotoxic filtrates by 16 $\pm 2 \%(P<0.001)$. Exogenous dibutyryl cyclic AMP $(2 \mathrm{mM})$ inhibited total PMN migration toward E. coli filtrates by $32 \%(P<0.001)$. PMN intracellular cyclic AMP levels increased by $220 \%$ after $2 \mathrm{~h}$ of incubation with purified $E$. coli enterotoxin. The decreased chemotactic attractiveness of enterotoxic E. coli filtrates appears to be related to the ability of enterotoxin to increase cyclic AMP in PMN. Enterotoxin production by $E$. coli may be advantageous to the microbe by decreasing its chemotactic appeal for PMN.

\section{INTRODUCTION}

Certain Escherichia coli produce a heat-labile enterotoxin which appears to cause noninflammatory watery diarrhea by stimulating intestinal mucosal adenylate cyclase (1-7). This enterotoxin, like cholera toxin, can also activate adenylate cyclase in various mammalian cells, thereby increasing intracellular concentrations of cyclic adenosine $3^{\prime}, 5^{\prime}$-monophosphate (cyclic AMP) ${ }^{1}$

\footnotetext{
${ }^{1}$ Abbreviations used in this paper: $\mathrm{CHO}$, Chinese hamster ovary; cyclic AMP, cyclic adenosine $3^{\prime}, 5^{\prime}$-monophosphate; MIX, 1-methyl-3-isobutylxanthine; PMN, polymorphonuclear neutrophils; Tox ${ }^{+}$, enterotoxigenic; Tox ${ }^{-}$, nonenterotoxigenic.
} 
and inducing characteristic alterations of cell morphology and function (8-11).

Increased intracellular cyclic AMP levels in polymorphonuclear neutrophils (PMN) inhibit phagocytosis, candidacidal activity $(12,13)$, granule discharge $(14,15)$, and chemotactic responsiveness (16). Therefore, enterotoxin production may be of benefit to the microorganism by increasing PMN intracellular cyclic AMP and altering the ability of the phagocyte to approach, ingest, and kill the microbes. We examined the interaction of human PMN with enterotoxigenic E. coli to determine the effect of enterotoxigenicity on the PMN-bacterial interaction.

\section{METHODS}

\section{Bacteria and bacterial filtrates}

Three enterotoxigenic [334 (015:H11), 711K12(P155) 2 , and 408-3(078: $\mathrm{H} 12)]$ and three nonenterotoxigenic [10405, $711 \mathrm{~K} 12$, and 408-4(078:H12)] $E$. coli strains were used to evaluate phagocytosis and killing by PMN. These strains were also used in measuring PMN postphagocytic hexose monophosphate shunt activity. Culture filtrates for chemotaxis assays were obtained from ten enterotoxigenic strains of $E$. coli [334, 711K12(P155) $)_{2}$, 408-3(078:H12), 19662, 9116, 17974, 19094, B2C(06:H16), B7A(0148:H28), and 19437] and five nonenterotoxigenic strains $[10405,711 \mathrm{~K} 12,408-4(078: \mathrm{H} 12), 1624(0144$ : $\mathrm{K}$ ?:H-), and 1272(0124:K72:H-)]. The paired strains 408-3 (078:H12) and 408-4(078:H12), as well as $711 \mathrm{~K} 12(\mathrm{P} 155)_{2}$ and $711 \mathrm{~K} 12$, are identical serotypes except that strains $408-3(078$ : $\mathrm{H} 12$ ) and $711 \mathrm{~K} 12(\mathrm{P} 155)_{2}$ contain a plasmid coding for the production of heat-labile enterotoxin $(3,5,17,18)$. Also studied was $E$. coli strain B44, which produces only a heat-stable toxin $(11,19)$, and strains 1624 and 1272 , which are invasive but nonenterotoxigenic.

To prepare bacterial culture filtrates, organisms were incubated for $24 \mathrm{~h}$ at $37^{\circ} \mathrm{C}$ in Media 199 (Microbiological Associates, Bethesda, Md.). The cultures were centrifuged at 2,000 $g$ for $15 \mathrm{~min}$, and the resulting supernatants were filtered through a $0.45-\mu \mathrm{m}$ micropore filter (Millipore Corporation, Bedford, Mass.).

\section{Purified E. coli enterotoxin}

Heat-labile $E$. coli enterotoxin was purified essentially as previously described (20-22). Crude toxin was extracted using polymyxin B and further purified by chromatography on inactivated Affi-Gel 202 (Bio-Rad Laboratories, Richmond, Calif.) affinity chromatography, gel filtration on Ultro-gel AcA44 (LKB), and passage through a P-150 (Bio-Rad) column. The resulting ultraviolet (UV)-absorbing peak that contained toxic activity, as demonstrated in the Chinese hamster ovary (CHO) cell assay (11), was dialyzed overnight against $0.1 \mathrm{M}$ $\mathrm{NH}_{4} \mathrm{HCO}_{3}$ and lyophilized. This material gives a single band on polyacrylamide electrophoresis. Antiserum against $E$. coli toxin was prepared in rabbits against enterotoxin from enterotoxigenic $E$. coli strain 23505 . This enterotoxin was partially purified by polymyxin release, $\left(\mathrm{NH}_{4}\right)_{2} \mathrm{SO}_{4}$ precipitation, and agarose-gel chromatography. The antiserum, designated antiserum 441 , has been previously described (21), and it neutralizes the biologic effects of purified cholera toxin and $E$. coli enterotoxin in $\mathrm{CHO}$ cells at dilutions greater than 1:8 and $1: 64$, respectively (23). Enterotoxin was used in a concentration of $0.33 \mathrm{mg} / \mathrm{ml}$ for all enterotoxin experiments. Purified cholera toxin, prepared by Dr. R. A. Finkelstein (24), was provided by Dr. Carl E. Miller (National Institute of Allergy and Infectious Diseases, Bethesda, Md.).

\section{Determination of enterotoxigenicity by $\mathrm{CHO}$ cell assay}

Enterotoxin production by strains of $E$. coli was determined by quantitating morphological alterations of $\mathrm{CHO}$ cells as previously described (11). The characteristic change in CHO morphology, from epithelial to elongated forms, appears to be mediated by enterotoxin activation of adenylate cyclase and a corresponding increase in intracellular cyclic AMP. This is supported by the observations that elevated cyclic AMP concentrations coincide with observed changes in CHO morphology, by the fact that phosphodiesterase inhibition potentiates this observed morphological effect, and by the occurrence of the morphological elongation after the addition of exogenous dibutyryl cyclic AMP (25).

\section{Microscopic observations of phagocytosis}

Leukocyte monolayers were prepared as previously described (26). The interaction of PMN with toxigenic and nontoxigenic $E$. coli was observed on a $37^{\circ} \mathrm{C}$ air curtain stage with phase contrast microscopy. Giemsa-stained smears of PMN$E$. coli interaction were also prepared and exarnined.

\section{Phagocytosis of ${ }^{14} \mathrm{C}$-labeled bacteria}

Modification of the method of Downey and Diedrich (27) was employed. Toxigenic or nontoxigenic $E$. coli were cultured for $18 \mathrm{~h}$ in trypticase soy broth with $10 \mu \mathrm{Ci} / \mathrm{ml}$ of ${ }^{14} \mathrm{C}$ labeled amino acid mixture (New England Nuclear, Boston, Mass.) and then washed in saline solution. $5 \times 10^{8}$ bacteria $/ \mathrm{ml}$ were added to $5 \times 10^{6} \mathrm{PMN} / \mathrm{ml}$, which were tumbled at $37^{\circ} \mathrm{C}$, and $0.2-\mathrm{ml}$ samples were removed at $0,5,10$, and $20 \mathrm{~min}$. The samples were placed in $4 \mathrm{ml}$ of iced Hanks' balanced salt solution (Microbiological Associates), with $10 \%$ fetal bovine serum and centrifuged at $100 \mathrm{~g}$ for $5 \mathrm{~min}$ at $4^{\circ} \mathrm{C}$. The cell buttons were washed, digested with Protosol (New England Nuclear), and counted in a Beckman LS250 scintillation counter (Beckman Instruments, Inc., Fullerton, Calif.).

\section{Phagocytosis and leukocyte bactericidal activity}

$10 \mathrm{ml}$ of heparinized venous blood from normal donors was sedimented for 60 min with an equal volume of $3 \%$ dextran. The supernatant fluid containing leukocytes was collected, erythrocytes remaining in the supernatant were lysed with iced distilled water, and tonicity was restored with hypertonic saline. Leukocytes were then centrifuged at $200 \mathrm{~g}$ for $12 \mathrm{~min}$, and the resulting cell button was resuspended in Hanks' balanced salt solution with $10 \%$ autologous serum. $4 \mathrm{ml}$ of suspension with $5 \times 10^{6}$ bacteria and $5 \times 10^{6} \mathrm{PMN} / \mathrm{ml}$ was tumbled at $37^{\circ} \mathrm{C}$, and samples were removed at specified times for determination of total, supernatant, and sediment viable bacterial counts (28). PMN were omitted in some experiments to determine the effect of serum on bacterial viability. Experiments were done with $(a) E$. coli washed three times with saline, $(b)$ whole culture suspensions, $(c)$ washed nonenterotoxigenic $E$. coli with addition of $2 \mu \mathrm{g} / \mathrm{ml}$ purified cholera toxin to the PMN $1 \mathrm{~h}$ before the addition of the bacteria, (d) washed enterotoxigenic $E$.coli resuspended in filtrate with 
or without enterotoxin, and $(e)$ washed nonenterotoxigenic $E$. coli resuspended in filtrate with or without enterotoxin.

\section{Determination of hexose monophosphate shunt activity of PMN}

Oxidation of glucose by PMN,E. coli, and PMN plus E. coli via the hexose monophosphate shunt was determined using $\left[1-{ }^{14} \mathrm{C}\right]$ glucose, as previously described (29).

\section{Chemotaxis studies}

A chemotaxis assay under agarose, as described by Nelson et al. (30), was used with agarose (Litex, Denmark; available from Accurate Chemical \& Scientific Corp., Hicksville, N. Y.) replacing agarose Indubiose. Leukocyte suspensions containing PMN and mononuclear cells were utilized, and chemotaxis was measured after $2 \mathrm{~h}$ of incubation. Nelson et al. have shown that PMN make up the vast majority of migrating cells after this period of incubation. Each agarose chemotaxis plate consists of six triplets of wells arranged in radial fashion, with one experiment performed in each triplet. The distance from the outer edge of the well containing PMN to the leading border of migrating cells was measured in coded plates without knowledge of well contents, utilizing a $\times 40-\mu \mathrm{m}$ eyepiece on a dissecting microscope.
PMN to filtrates and media. The following chemotaxis assays were run to determine migration toward enterotoxic $\left(\mathrm{Tox}^{+}\right)$and nonenterotoxic $\left(\mathrm{Tox}^{-}\right)$filtrates vs. Media 199 (Fig. 1): (a) PMN (center well) migrating to Tox filtrates and to Media 199 (outer wells); (b) PMN (center well) migrating to $\mathrm{Tox}^{+}$filtrates and to Media 199 (outer wells). For these assays, chemotactic (directed) migration was determined by subtracting the distance moved toward the media control from the distance moved towards the bacterial filtrates.

$P M N$ to filtrates. To compare migration to filtration from the same well of PMN, we set up the following assays (Fig. 2): (a) PMN (center well) migrating to $\mathrm{Tox}^{+}$and $\mathrm{Tox}^{-}$filtrates (outer wells); (b) PMN (center well) to heated $\left(65^{\circ} \mathrm{C}\right.$ for 30 min) $\mathrm{Tox}^{+}$and heated or nonheated Tox filtrates (outer wells); (c) PMN (center well) to $\mathrm{Tox}^{+}$filtrates with antiserum to enterotoxin and Tox filtrates with or without antiserum to enterotoxin (outer wells); and (d) PMN plus $0.1 \mathrm{mM}$ 1-methyl3-isobutylxanthine (MIX) (Aldrich Chemical Co., Inc., Milwaukee, Wis.) (center well) to $\mathrm{Tox}^{+}$and Tox ${ }^{-}$filtrates (outer wells). Results of these assays are expressed by considering total migration distance to Tox ${ }^{-}$filtrates as $100 \%$.

PMN plus additions. To test additions to PMN migrating to the same chemotactic stimulus, we performed the following assays (Fig. 3): (a) PMN (outer well) and PMN plus cholera toxin (other outer well) to Tox filtrate (center well); (b) PMN (outer well) and PMN plus dibutyryl cyclic AMP (other outer well) to $\mathrm{Tox}^{-}$filtrate or Media 199 (center well); (c) PMN (outer well) and PMN plus MIX (other outer well) to Tox ${ }^{-}$

\section{a) Tox ${ }^{-}$versus Media 199}
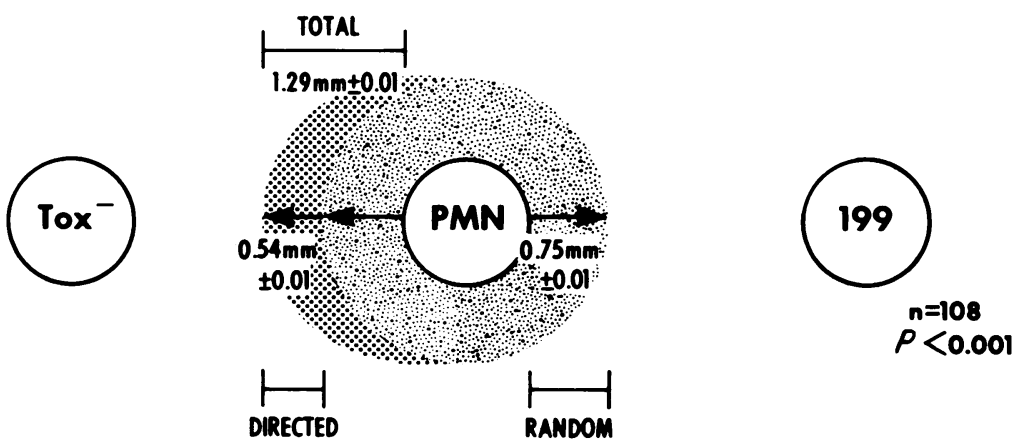

b) Tox ${ }^{+}$versus Media 199
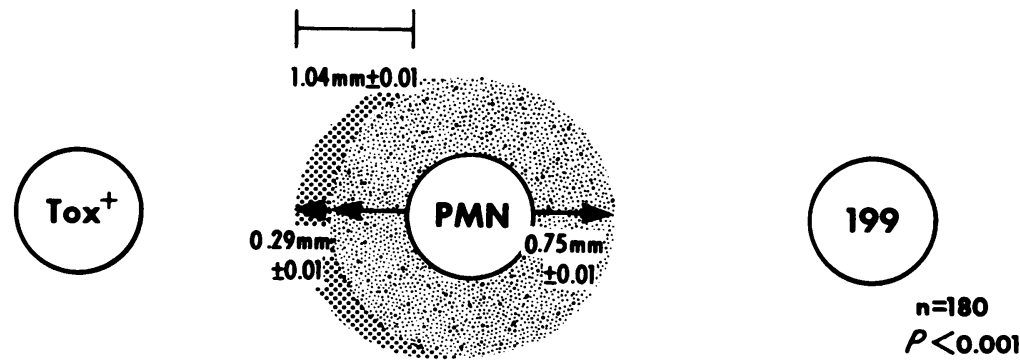

FIgURE 1 PMN migration toward E. coli filtrates and Media 199. Migration of PMN toward equidistant $E$. coli filtrates and Media 199 was quantitated after 2-h incubation. Random migration is the distance the cell front moves toward Media 199; directed (chemotactic) migration is the distance the cell front moves toward the filtrate minus the random migration. Migration distances are expressed as mean $\pm \mathrm{SEM} ; n=$ number of observations; $P$ values obtained with Student's $t$ test using paired data. 
(a) Tox ${ }^{+}$versus Tox ${ }^{-}$
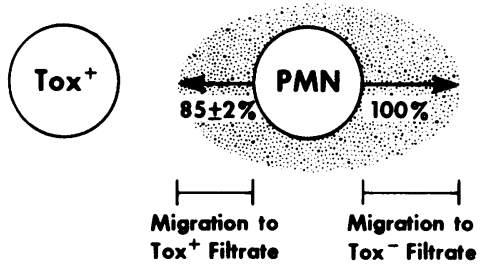

(b) Heated $(\Delta)$ Tox $^{+}$versus Tox ${ }^{-}$
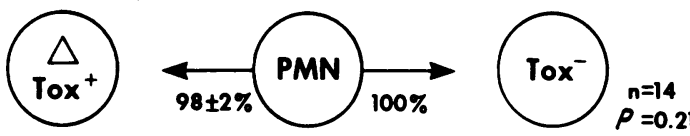

(c) Tox: with antitoxin (AT) versus Tox
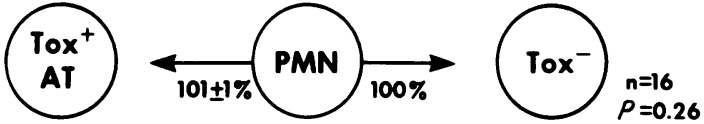

(d) 1-Methyl-3-Isobutylxanthine (MIX) with PMN
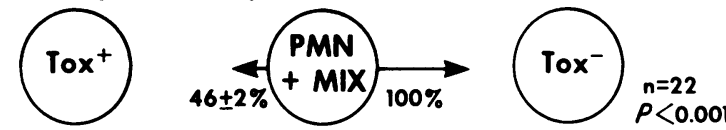

FIgURE 2 PMN migration toward E. coli filtrates. Migration of PMN toward two equidistant chemotactic stimuli was quantitated after a 2 -h incubation. The migration distance toward $\mathrm{Tox}^{-}$filtrate is considered to be $100 \%$. Migration toward $\mathrm{Tox}^{+}$filtrates is expressed as the mean \pm SEM percent of migration toward Tox ${ }^{-}$filtrate.

filtrate or Media 199 (center well). Results of these assays are expressed by considering total migration distance of PMN without additions as $100 \%$.

PMN plus purified E. coli enterotoxin. To study the effect of the purified enterotoxin, we performed the following experiments (Fig. 4): (a) PMN (center well) to Tox ${ }^{-}$filtrate with or without purified E. coli enterotoxin (outer wells); (b) PMN with or without purified $E$. coli enterotoxin (outer wells) to Tox ${ }^{-}$filtrate incubated for $2 \mathrm{~h}$; $(c)$ as $b$, but incubated for $4 \mathrm{~h}$.

\section{Effect of purified E. coli enterotoxin and MIX on PMN cyclic AMP concentrations}

PMN were obtained by Ficoll-Hypaque separation (31) followed by dextran sedimentation and hypotonic lysis of the residual erythrocytes. $5 \times 10^{6} \mathrm{PMN}(0.4-0.8 \mathrm{mg}$ of protein) were tumbled at $37^{\circ} \mathrm{C}$ in $0.5 \mathrm{ml}$ of Hanks' balanced salt solution without bicarbonate with purified $E$. coli enterotoxin $(0.33 \mathrm{mg} /$ $\mathrm{ml})$, MIX $(0.05 \mathrm{mM})$, both, or neither. Samples were run in duplicate in experiment 1 and in triplicate in experiment 2. In experiment 2 , cell suspensions were incubated at $37^{\circ} \mathrm{C}$ for 15 min before any additions were made. After $2 \mathrm{~h}$,incubations were terminated with the addition of $50 \mu \mathrm{l}$ of $60 \%$ trichloroacetic acid. Samples were extracted, acetylated, and assayed for cyclic AMP with a radioimmunassay procedure (32), as described previously (33). Protein was determined by the method of Lowry et al. (34).

\section{RESULTS}

\section{Microscopic observations of phagocytosis}

Examination of stained smears and of living preparations with phase contrast microscopy suggested that most cell-associated $E$. coli were internalized.

\section{Phagocytosis of ${ }^{14} \mathrm{C}$-labeled bacteria}

Both toxigenic and nontoxigenic $E$. coli became cell associated to a similar rate and degree (Fig. 5), suggesting equivalent phagocytosis by PMN.

\section{Phagocytosis and killing}

The E. coli strains utilized were not killed by serum alone. Enterotoxigenic and nonenterotoxigenic E. coli were removed from the supernate at a similar rate and to a similar degree after incubation with PMN. After $60 \min , 98.0 \pm 1.7 \%(n=5)$ of the Tox ${ }^{-}$E. coli and 98.9

(a) Cholera Toxin (CT)
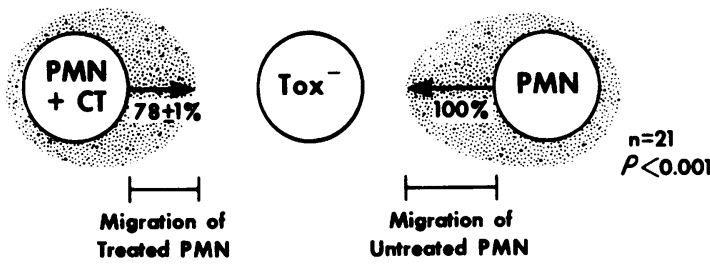

(b) Dibutyryl cylcic AMP (DBCA)

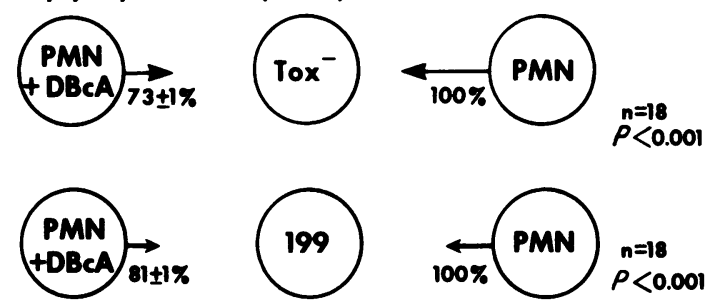

(c) 1-Methyl-3-Isobutylxanthine (MIX)
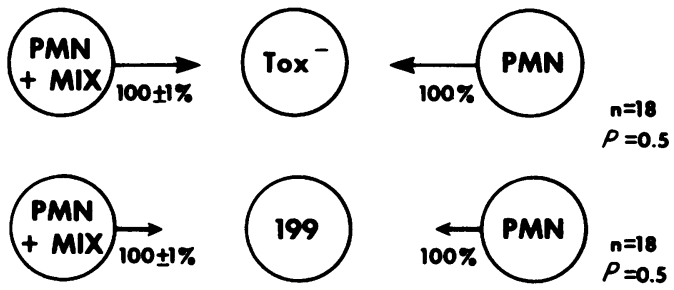

FIGURE 3 Effects of additives on PMN migration toward E. coli filtrates and Media 199. Migration of PMN toward Tox ${ }^{-}$filtrates was compared with migration of $P M N$ plus either cholera toxin $(1 \mu \mathrm{g} / \mathrm{ml})$, dibutyryl cyclic AMP $(2 \mathrm{mM})$, or MIX $(0.1 \mathrm{mM})$ toward the same stimulus. PMN were pretreated with cholera toxin for $90 \mathrm{~min}$. The migration distance of the untreated PMN is considered to be $100 \%$. 
(a) Tox $^{-}+$Toxin vs. Tox
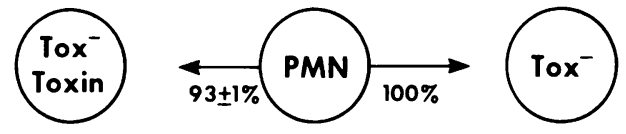

$n=23$
$\rho<0.001$

(b) $P M N+$ Toxin vs. $P M N-2 h$
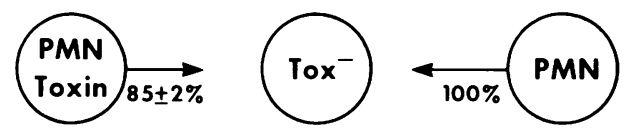

$\mathrm{n}=\mathbf{2 1}$

$p<0.001$

(c) PMN + Toxin vs. PMN-4h
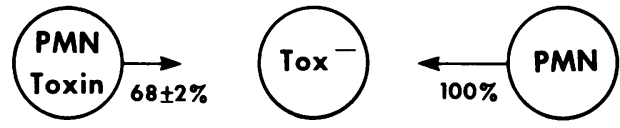

$n=10$

$p<0.001$

Figure 4 Effect of purified E. coli enterotoxin on PMN migration. Migration of PMN toward $\mathrm{Tox}^{-}$filtrates (migration distance considered as $100 \%$ ) was compared with migration toward $\mathrm{Tox}^{-}$filtrate plus purified enterotoxin. $(b)$ and $(c)$ depict experiments done with the addition of purified enterotoxin directly to the PMN. Migration distance of the untreated PMN is considered to be $100 \%$.

$\pm 1.0 \%(n=5)$ of the $\mathrm{Tox}^{+} E$. coli had been removed from the supernate and $97.6 \pm 1.5 \%(n=5)$ and 98.7 $\pm 0.7 \%(n=5)$, respectively, had been killed. By 120 $\min , 99.3 \pm 0.5 \%(n=5)$ of the Tox ${ }^{-} E$. coli and 99.5 $\pm 0.4 \%(n=5)$ of the $\mathrm{Tox}^{+} E$. coli had been removed from the supernate and $98.1 \pm 1.5 \%(n=5)$ and 99.3 $\pm 0.5 \%(n=5)$, respectively, had been killed. These differences are not significant and thus PMN ingest and kill toxigenic and nontoxigenic $E$. coli equally well in this tumbling system. Suspension of the bacteria in culture media or incubation of PMN for $1 \mathrm{~h}$ with cholera toxin $(2 \mu \mathrm{g} / \mathrm{ml})$ or purified E. coli enterotoxin $(0.33 \mu \mathrm{g} /$ ml) did not alter the results.

\section{Bacterial stimulation of PMN hexose monophosphate shunt activity.}

There were equivalent increases in hexose monophosphate shunt activity after incubation with both the enterotoxigenic and nonenterotoxigenic strains of $E$. coli, suggesting equivalent ingestion and PMN stimulation (Table I).

\section{Chemotaxis}

Both enterotoxigenic and nonenterotoxigenic strains of $E$. coli showed equivalent growth rates over an 18-h growth period, each reaching 1.8-2.0 $\times 10^{9}$ colony forming units $/ \mathrm{ml}$. Thus filtrates were prepared from cultures with equivalent growth.

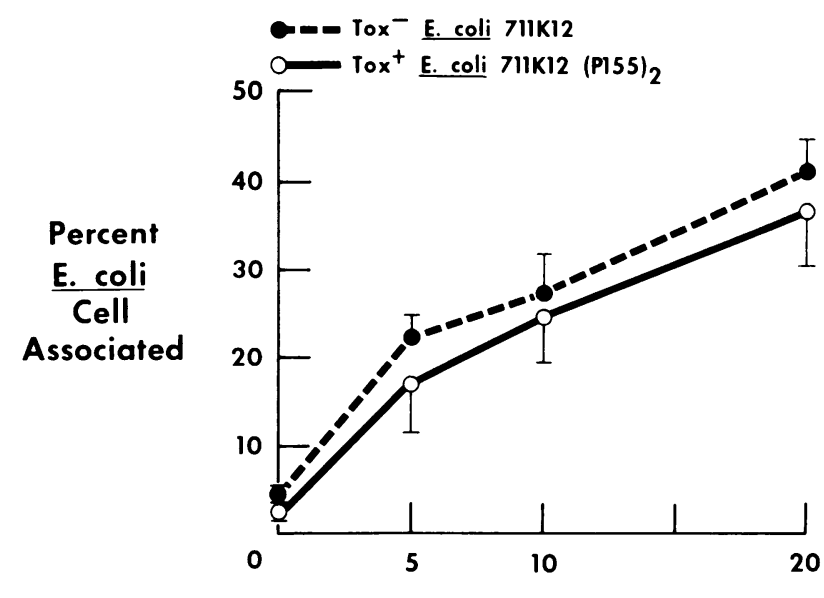

Minutes

Figure 5 Phagocytosis of ${ }^{14} \mathrm{C}$-labeled bacteria. The percent of ${ }^{14} \mathrm{C}$-labeled toxigenic and nontoxigenic $E$. coli associated with PMN is depicted at various incubation times. Mean \pm SEM for nine determinations at each time period are shown. The two curves can be considered identical by comparison of the regression lines $P=0.42(35)$.

PMN to filtrates and media. PMN total migration toward Tox ${ }^{-}$filtrates was $1.29 \pm 0.01 \mathrm{~mm}$ and toward $\mathrm{Tox}^{+}$filtrates was $1.04 \pm 0.01 \mathrm{~mm}$. Since migration toward Media 199 (random migration) was $0.75 \pm 0.01$ $\mathrm{mm}$, chemotactic migragtion toward Tox ${ }^{-}$filtrates was $0.54 \pm 0.01 \mathrm{~mm}$ and toward $\mathrm{Tox}^{+}$filtrates was $0.29 \pm 0.01$ $\mathrm{mm}(P<0.001)$. Chemotactic migration toward $\mathrm{Tox}^{+}$ filtrates was thus $46 \%$ less than that toward $\mathrm{Tox}^{-}$ filtrates (Fig. 1).

$P M N$ to filtrates. PMN migration toward filtrates from paired enterotoxigenic and nonenterotoxigenic $E$. coli strains also showed a significant decrease in total (random plus chemotactic) migration toward the en-

TABLE I

Hexose Monophosphate Shunt Activity

\begin{tabular}{lcrr}
\hline & $\begin{array}{c}\text { Experi- } \\
\text { ment 1 }\end{array}$ & $\begin{array}{c}\text { Experi- } \\
\text { ment 2 }\end{array}$ & $\begin{array}{r}\text { Experi- } \\
\text { ment 3 }\end{array}$ \\
\hline & & ${ }^{14} \mathrm{CO}_{2}$ cpm & \\
E. coli (toxigenic), no PMN & 4,055 & 8,697 & 5,637 \\
$\begin{array}{l}\text { E. coli } \text { (nontoxigenic), no } \\
\text { PMN }\end{array}$ & 4,281 & 6,397 & 4,761 \\
PMN & 2,224 & 1,732 & 1,271 \\
PMN plus E. coli (toxigenic) & 7,903 & 14,097 & 13,337 \\
PMN plus E. coli & & & \\
$\quad$ (nontoxigenic) & 9,676 & 12,225 & 12,541 \\
\hline
\end{tabular}

$\left[1-{ }^{14} \mathrm{C}\right]$ glucose oxidation by $5 \times 10^{8} \mathrm{E}$. coli, $10^{7} \mathrm{PMN}$, and $5 \times 10^{8}$ E. coli plus $10^{7}$ PMN. Both enterotoxigenic E. coli [408-3(078: H12)] and nonenterotoxigenic $E$. coli [408-4 (078: $\mathrm{H} 12)]$ caused an equivalent increase in $\left[1-{ }^{14} \mathrm{C}\right]$ glucose oxidation by PMN. 


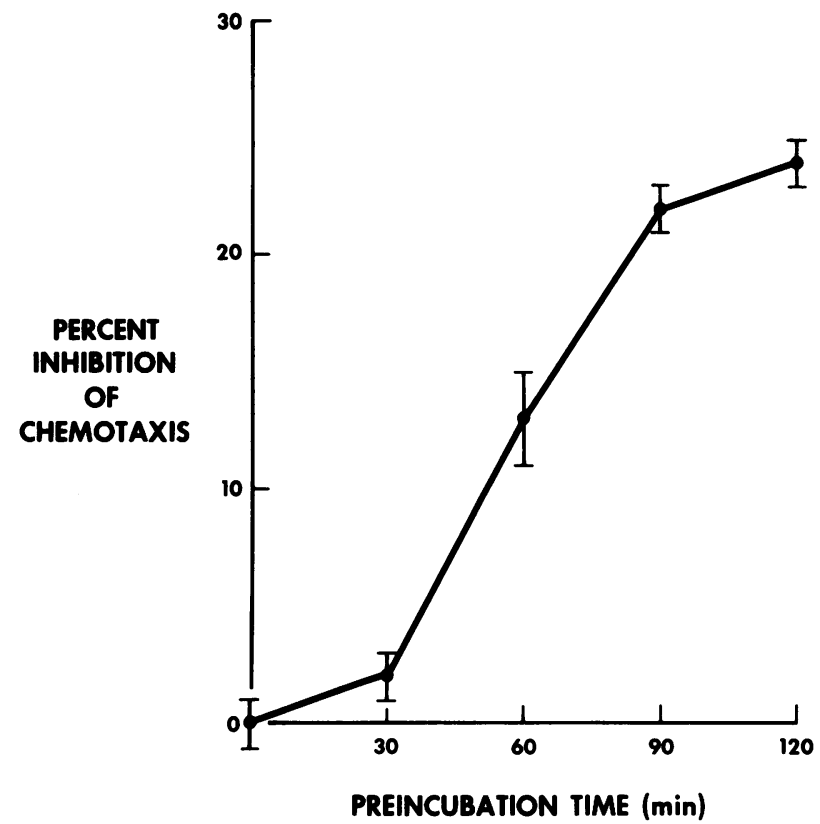

FIGURE 6 Time course of cholera toxin effect on PMN chemotaxis. PMN were preincubated with cholera toxin $(1 \mu \mathrm{g} / \mathrm{ml})$, and then migration toward nonenterotoxigenic $E$. coli filtrates was measured. Results were compared with PMN incubated without cholera toxin. The percent inhibition of chemotaxis is plotted against incubation time. Mean \pm SEM for 13-21 determinations at each time period are shown. Percent inhibition of chemotaxis $=1-$ (Migration distance of $\mathrm{PMN}+\mathrm{CT} / \mathrm{Mi}$ gration distance of PMN).

terotoxic filtrate from each pair (Fig. $2 a$ ). Migration toward the nonenterotoxic filtrates was considered to be $100 \%$ for each pair. Invasive $E$. coli and $E$. coli that produce only the heat-stable toxin were as chemotactic for PMN as were nonenterotoxigenic E. coli. The inhibition of PMN chemotaxis by enterotoxic filtrates was eliminated by heating at $65^{\circ} \mathrm{C}$ for $30 \mathrm{~min}$ to destroy the heat-labile enterotoxin (Fig. $2 b$ ) and by the addition of antisera prepared against $E$. coli enterotoxin (Fig. $2 c)$. Neither heat nor antiserum prepared against $E$. coli enterotoxin influenced migration to Tox filtrates.

Addition of the phosphodiesterase inhibitor, MIX, to the PMN (Fig. $2 d$ ), in order to potentiate any effect due to an increase in intracellular concentrations of cyclic AMP, resulted in a threefold increase in inhibition of PMN chemotaxis toward enterotoxic filtrate, compared with chemotaxis toward nonenterotoxic filtrate. MIX alone did not affect migration to $\mathrm{Tox}^{-}$filtrates or to Media 199 (Fig. $3 c$ ).

PMN plus additions. Addition of cholera toxin (1 $\mu \mathrm{g} / \mathrm{ml}$ ) directly to the PMN well decreased migration of PMN to E. coli filtrates after a lag period (Fig. $3 a$ ). Although addition of cholera toxin $(1 \mu \mathrm{g} / \mathrm{ml})$ to the nonenterotoxic filtrate did not diminish migration of PMN, incubation of cholera toxin in the wells for $4 \mathrm{~h}$ before addition of $\mathrm{PMN}$ and the Tox ${ }^{-}$filtrates decreased migration by $13 \pm 2 \%(n=18, P<0.001)$. The relationship of inhibition of chemotaxis and time of incubation with cholera toxin is shown in Fig. 6. The effect could not be eliminated by washing off the cholera toxin after preincubation with PMN for only 5 min.

Addition of exogenous dibutyryl cyclic AMP to PMN resulted in marked inhibition of PMN movement toward a chemotactic stimulus and also inhibited random movement (Fig. $3 b$ ).

PMN plus purified E. coli enterotoxin. Addition of the purified $E$. coli enterotoxin directly to the Tox ${ }^{-}$ filtrates resulted in a $7 \%$ diminution of chemotaxis. When added directly to the PMN with a 2-h or 4-h incubation, there was $15 \%$ and $32 \%$, respectively, diminished lotal migration towards Tox- filtrates (Fig. 4).

\section{Effect of purified E. coli enterotoxin on PMN cyclic AMP}

Incubation with enterotoxin significantly increased PMN cyclic AMP levels, and this was amplified with the addition of MIX (Table II).

\section{DISCUSSION}

E. coli enterotoxin stimulates the adenylate cyclase activity of mammalian cells and subsequently increases intracellular cyclic AMP. Intracellular cyclic nucleo-

TABLE II

Effect of E. coli Enterotoxin and MIX on Cyclic AMP Levels in Incubations of Polymorphonuclear Leukocytes

\begin{tabular}{lc}
\hline \multicolumn{1}{c}{ Addition } & Cyclic AMP \\
\hline & pmol/mg protein \\
Experiment 1 & $5.97 / 3.91$ \\
None & $14.65 / 13.00$ \\
Enterotoxin & $6.69 / 9.79$ \\
MIX & $32.76 / 31.28$ \\
Enterotoxin + MIX & \\
Experiment 2 & $2.63 \pm 0.31$ \\
None & $4.28 \pm 0.11^{*}$ \\
Enterotoxin & $5.04 \pm 0.79^{*}$ \\
MIX & $10.07 \pm 0.51^{*}$ \\
Enterotoxin + MIX & \\
\hline
\end{tabular}

$5 \times 10^{6}$ PMN were incubated with or without $0.05 \mathrm{mM}$ MIX and $0.33 \mathrm{mg} / \mathrm{ml}$ purified $E$. coli enterotoxin. In experiment 2 , cells were preincubated for 15 min before additions. After 120-min incubation, cyclic AMP was determined by radioimmune assay. Values in experiment 1 are from duplicate incubations and values in experiment 2 are means \pm SEM of triplicate incubations.

* Significantly different from "none" $(P<0.03)$.

† Significantly different from enterotoxin alone and MIX alone $(P<0.002)$. 
tides may function as an important modulator of PMN function. Increased intracellular concentrations of cyclic guanosine 3',5'-monophosphate (cyclic GMP) enhance chemotaxis $(36,37)$, while increased intracellular concentrations of cyclic AMP inhibit rabbit PMN chemotaxis (16). Studies also suggest that the ability of PMN to phagocytize, degranulate, and kill may be inhibited by cyclic AMP (12-15). We noted that PMN were able to ingest and kill enterotoxigenic and nonenterotoxigenic $E$. coli equally well. The phagocytosis system used entails tumbling bacteria and PMN together so that active movement by PMN plays a relatively minor role.

In contrast to the lack of effect of enterotoxin upon phagocytosis and killing in suspensions of PMN, there was a consistent impairment of chemotaxis of PMN toward enterotoxigenic $E$. coli filtrates. One possible explanation for this effect is that chemotactic factors are less active in the Tox $^{+}$filtrates. A second possibility is that a substance in the Tox ${ }^{-}$filtrates destroys a chemotaxis inhibitor. Against both of these possibilities are the observations that chemotaxis to $\mathrm{Tox}^{+}$filtrates is restored to that of $\mathrm{Tox}^{-}$filtrates by inactivating the heat-labile enterotoxin with specific antiserum or heat. Furthermore, chemotaxis inhibition by enterotoxin is enhanced by MIX, an effect that is best explained by the action of enterotoxin upon PMN adenylate cyclase.

Our data strongly suggest that inhibition of PMN migration toward Tox ${ }^{+}$filtrates is due to the enterotoxin itself. This is substantiated by the following observations: (a) Filtrates from enterotoxigenic $E$. coli are consistently less chemotactic for human PMN than are nonenterotoxigenic $E$. coli filtrates prepared from serotypes of $E$. coli identical except for the plasmid coding for enterotoxin. (b) Inactivation of the heat-labile enterotoxin at $65^{\circ} \mathrm{C}$ for $30 \mathrm{~min}$, or inactivation by antisera to enterotoxin, eliminates the inhibition of chemotaxis noted with $\mathrm{Tox}^{+}$filtrates. (c) Addition of purified $E$. coli enterotoxin to nonenterotoxic filtrates or directly to PMN significantly decreases PMN chemotactic migration.

The inhibition of PMN chemotaxis by enterotoxin appears to be due to an increase in intracellular cyclic AMP induced by the enterotoxin because of the following: (a) The reports of others (16) and our observations with the direct addition of dibutyryl cyclic AMP to PMN show that increased cyclic AMP concentrations are associated with decreased chemotactic responsiveness. (b) The time course of cholera toxin effect on PMN chemotaxis is consistent with the temporal effects of cholera toxin on adenylate cyclase activation in intestinal tissue (38) and on cyclic AMP increases in other tissues $(6,9,10,11)$; (the addition of cholera toxin to wells containing Tox ${ }^{-}$filtrate inhibits PMN chemotaxis only after sufficient time is allowed for the larger cholera toxin molecule $[84,000$ daltons vs. 23,500 daltons] to diffuse through the agar $[39,40]) .(c)$ The addition of a phosphodiesterase inhibitor decreased migration to $\mathrm{Tox}^{+}$filtrates but not to Tox ${ }^{-}$filtrates, probably by potentiating increased intracellular cyclic AMP induced by the enterotoxin. (d) Finally, we noted significant increases in PMN cyclic AMP concentrations after incubation with purified $E$. coli enterotoxin. Furthermore, cyclic AMP effects in PMN incubated with enterotoxin are enhanced by the phosphodiesterase inhibitor MIX. The use of purified cell preparations in these studies indicates that the cylic AMP increases occur specifically in PMN.

In conclusion, the heat-labile enterotoxin produced by $E$. coli may be advantageous to the microbe by decreasing its chemotactic appeal for PMN.

\section{ACKNOWLEDGMENTS}

We thank Gail Sullivan and Deborah Conard for expert technical assistance and Lillian Robertson for skillfully typing the manuscript.

This work was supported in part by U.S. Public Health Service grants AI-09504, AI-42548, and HL-18260.

\section{REFERENCES}

1. Gorbach, S. L., B. H. Kean, D. G. Evans, Jr., and D. Bessudo. 1975. Traveler's diarrhea and toxigenic Escherichia coli. N. Engl. J. Med. 292: 933-936.

2. Guerrant, R. L., R. A. Moore, P. M., Kirschenfeld, and M. A. Sande. 1975. Role of toxigenic and invasive bacteria in acute diarrhea of childhood. N Engl.J. Med. 293: $567-573$.

3. Sack, R. B., S. L. Gorbach, J. G. Banwell, B. Jacobs, B. D. Chatterjee, and R. C. Mitra. 1971. Enterotoxigenic Escherichia coli isolated from patients with severe cholera-like disease. J. Infect. Dis. 123: 378-385.

4. Merson, M. H., G. K. Morris, D. A. Sack, J. G. Wells, J. C. Feeley, R. B. Sack, W. B. Creech, A. Z. Kapikian, and E. J. Gangarosa. 1976. Travelers' diarrhea in Mexico. N. Engl. J. Med. 294: 1299-1305.

5. Evans, D. J., Jr., L. C. Chen, G. T. Curlin, and D. G. Evans. 1972. Stimulation of adenyl cyclase by Escherichia coli enterotoxin. Nat. New Biol. 236: 137-138.

6. Kantor, H. S., P. Tao, and L. Wisdom. 1974. Action of Escherichia coli enterotoxin: adenylate cyclase behavior of intestinal epithelial cells in culture. Infect. Immun. 9: 1003-1010.

7. Guerrant, R. L., U. Ganguly, A. G. T. Casper, E. J. Moore, N. F. Pierce, and C. C. J. Carpenter. 1973. Effects of Escherichia coli on fluid transport across canine small bowel: mechanism and time course with enterotoxin and whole bacterial cells. J. Clin. Invest. 52: 1707-1714.

8. Donta, S. T., H. W. Moon, and S. C. Whipp. 1974. Detection of Escherichia coli enterotoxin with the use of adrenal cells in tissue culture. Science (Wash. D.C.). 183; 334-335.

9. Mashiter, K., G. D. Mashiter, R. L. Haugher, and J. B. Field. 1973. Effects of cholera and E. coli enterotoxins on cyclic adenosine $3^{\prime}, 5^{\prime}$-monophosphate levels and intermediary metabolism in the thyroid. Endocrinology. 92: $541-549$.

10. Hewlett, E. L., R. G. Guerrant, D. J. Evans, Jr., and W. B. Greenough III. 1974. Toxins of Vibrio cholerae and Esch- 
erichia coli stimulate adenyl cyclase in rat fat cells. Nature (Lond.). 249: 371-373.

11. Guerrant, R. L., L. L. Brunton, T. C. Schnaitman, L. I. Rebhun, and A. G. Gilman. 1974. Cyclic adenosine monophosphate and alteration of Chinese hamster ovary cell morphology: a rapid, sensitive in vitro assay for enterotoxins of Vibrio cholerae and Escherichia coli. Infect. Immun. 10: 320-327.

12. Cox, J. D., and M. L. Karnovsky. 1973. The depression of phagocytosis by exogenous cyclic nucleotides, prostaglandins and theophylline. J. Cell. Biol. 59: 480-490.

13. Bourne, H. R., R. I. Lehrer, M. J. Cline, and K. K. Melmon. 1971. Cyclic adenosine $3^{\prime}, 5^{\prime}$-monophosphate in the human leukocyte: synthesis, degradation and effects on neutrophil candidacidal activity. J. Clin. Invest. 50: 920929.

14. Weissmann, G., R. B. Zurier, and S. Hoffstein. 1972. Leukocytic proteases and the immunologic release of lysosomal enzymes. Am. J. Pathol. 68: 539-559.

15. Zurier, R. B., G. Weissman, S. Hoffstein, S. Kammerman, and H. H. Tai. 1974. Mechanisms of lysosomal enzyme release from human leukocytes. II. Effects of cAMP, cGMP, autonomic agonists, and agents which affect microtubule function. J. Clin. Invest. 53: 297-309.

16. Rivkin, I., J. Rosenblatt, and E. L. Becker. 1975. The role of cyclic AMP in the chemotactic responsiveness and spontaneous motility of rabbit peritoneal neutrophils: the inhibition of neutrophil movement and the elevation of cyclic AMP levels by catecholamines, prostaglandins, theophylline and cholera toxin. J. Immunol. 15: 11261134.

17. DuPont, H. L., S. B. Formal, R. B. Hornick, M. J. Snyder, J. P. Libonati, D. G. Sheahan, E. H. LaBrec, and J. P. Kalas. 1971. Pathogenesis of Escherichia coli diarrhea. N. Engl. J. Med. 285: 1-9.

18. Gorbach, S. L., J. G. Banwell, B. D. Chatterjee, B. Jacobs, and R. B. Sack. 1971. Acute undifferentiated human diarrhea in the tropics. I. Alterations in intestinal microflora. J. Clin. Invest. 50: 881-889.

19. Giannella, R. A. 1976. Suckling mouse model for detection of heat-stable Escherichia coli enterotoxin: characteristics of the model. Infect. Immun. 14: 95-99.

20. Evans, D. J., Jr., D. G. Evans, and S. L. Gorbach. 1974. Polymyxin B-induced release of low-molecular-weight, heat-labile enterotoxin from Escherichia coli. Infect. Immun. 10: 1010-1017.

21. Evans, J. J. Jr., D. G. Evans, S. L. Gorbach, and S. H. Richardson. 1976. Purification of the polymixin-released, heat-labile enterotoxin of Escherichia coli. J. Infect. Dis. 133(Suppl): S97-S102.

22. Richardson, S. H., D. E. Lockwood, and W. McKenzie. 1975. Phenotypic properties of tox ${ }^{+}$and tox ${ }^{-}$strains of enterotoxigenic $E$. coli. Proceedings of the U.S.-Japan Cooperative Medical Sciences Program. XI Joint Cholera Conference. 100-111.

23. Guerrant, R. L., and L. L. Brunton. 1977. Characterization of the Chinese hamster ovary cell assay for the enterotoxins of Vibrio cholerae and Escherichia coli and for antitoxin: differential inhibition by gangliosides, specific antisera and toxoid. J. Infect. Dis. 135: 720-728.
24. Finkelstein, R. A., and J. J. LoSpalluto. 1970. Production, purification and assay of cholera toxin. Production of highly purified choleragen and choleragenoid. J. Infect. Dis. 121S: S63-S72.

25. Hsie, A. W., and T. T. Puck. 1971. Morphological transformation of Chinese hamster cells by dibutyryl adenosine cyclic $3^{\prime}, 5^{\prime}$-monophosphate and testosterone. Proc. Natl. Acad. Sci. U.S.A. 68: 358-361.

26. Dilworth, J. A., J. O. Hendley, and G. L. Mandell. 1975. Attachment and ingestion of gonococci by human neutrophils. Infect. Immun. 11: 512-516.

27. Downey, R. J., and B. F. Diedrich. 1968. A new method for assessing particle ingestion by phagocytic cells. Exp. Cell Res. 50: 483-489.

28. Mandell, G. L., and E. W. Hook. 1969. Leukocyte function in chronic granulomatous disease of childhood: studies on a 17 year old boy. Am. J. Med. 47: 473-486.

29. Mandell, G. L. 1972. Staphylococcal infection and leukocytic bacterial defect in a 22 year old woman. Arch. Intern. Med. 130: 754-757.

30. Nelson, R. B., P. G. Quie, and R. L. Simmons. 1975. Chemotaxis under agarose: a new and simple method for measuring chemotaxis and spontaneous migration of human polymorphonuclear leukocytes and monocytes. J. Immunol. 155: 1650-1656.

31. Boyum, A. 1968. Isolation of mononuclear cells and granulocytes from human blood. Scand. J. Clin. Lab. Invest. 21 (Suppl 97): 77-89.

32. Steiner, A. L., C. W. Parker,and D. M. Kipnis. 1972. Radioimmunoassay for cyclic nucleotides I. Preparation of antibodies and iodinated cyclic nucleotides. J. Biol. Chem. 247: 1106-1113.

33. Katsuki, S., and F. Murad. 1977. Regulation of adenosine cyclic $3^{\prime}, 5^{\prime}$-monophosphate and guanosine cyclic $3^{\prime}, 5^{\prime}$ monophosphate levels and contractility in bovine tracheal smooth muscle. Mol. Pharmacol. 13: 330-341.

34. Lowry, O. H., N. J. Rosebrough, A. L. Farr, and R. J. Randall. 1951. Protein measurement with the Folin phenol reagent. J. Biol. Chem. 193: 265-275.

35. Diem, K., and C. Lentner. 1970. Documenta Geigy Scientific Tables. Basel, Switzerland, CIBA-GEIGY Ltd. 178-179.

36. Estenson, R. B., H. R. Hill, G. Quie, N. Hogan, and N. D. Goldberg. 1973. Cyclic GMP and cell movement. Nature (Lond.). 245: 458.

37. Anderson, R., A. Glover, H. J. Koornhof, and A. R. Rabson. 1976. In vitro stimulation of neutrophil motility by levamisole: maintenance of cGMP levels in chemotactically stimulated levamisole-treated neutrophils. J. Immunol. 117: 428-432.

38. Guerrant, R. L., L. C. Chen, and G. W. G. Sharp. 1972. Intestinal adenyl-cyclase activity in canine cholera: correlation with fluid accumulation. J. Infect. Dis. 125: 377381.

39. Gill, M. D., D. J. Evans, Jr., and D. G. Evans. 1976. Mechanism of activation of adenylate cyclase in vitro by polymyxin-released, heat-labile enterotoxin of Escherichia coli. J. Infect. Dis. 133(Suppl): S103-S107.

40. Holmgren, J., and I. Lonnroth. 1976. Cholera toxin and the adenylate cyclase-activity signal. J. Infect. Dis. 133 (Suppl): 564-574. 